\title{
Strengthening the management of scientific research funds and improving the efficiency of scientific research funds
}

\author{
Yu Yang ${ }^{a}, \quad$ Liu Xianjiao ${ }^{b}$ \\ Jilin Agricultural University, Xincheng Street Jingyue District of Jilin province China Changchun No. \\ 2888 , \\ E-mail: ayuyang0082@163.com, b214132114@qq.com
}

Key words: scientific research funds management efficiency

\begin{abstract}
.
The management of scientific research funds is the most important part of scientific research management in universities. Scientific and standardized management methods can greatly improve the efficiency of scientific research funds. Based on the actual work, this paper discusses the situation, the management, the present situation, the problems and the solutions of the research fund management in universities.

Any of various research funding for the development of science and technology and the expenses, usually by the government, enterprises, non-governmental organizations and fund the delegate or the application report screening to distribution, is used to solve the problem of science and technology specific.

According to different sources, research funding can be divided into vertical research funding and horizontal research funding. Longitudinal research funding usually directly funded by the financial department of the government, the implementation of the budget management, implementation of the relevant fund management method; source of transverse scientific research funds in enterprises and institutions and other organizations, the implementation of the contract management, in accordance with the expenditure scope stipulated by the contract.

The management of scientific research funds in universities occupies a very important position in the overall scientific research. The standardization of management of scientific research funds and the rationality of management constitution directly affect the development of scientific research work in universities.
\end{abstract}

\section{The situation of the use and management of research funds}

Since 11th Five-Year, the use of scientific research funds has been paid more and more attention by the state and the provinces and cities. The Ministry of finance,

Ministry of science and technology jointly issued the "notice" provisions on the

adjustment of national science and technology plan and public welfare industry research special funds management approach, the Ministry of Education issued "on the further implementation of the policy of national scientific research funds management, strengthen the management of university research funding notice", the Education Department of Jilin Province, revised the "implementation of higher schools in Jilin research of special funds management rules"; Premier Wen Jiabao at the national science and technology education leading group meeting, the Commission in the Ministry of education and the discipline inspection team leader Wang Liying in 
the education system of honest government work conference has made an important speech, made a request for the management of scientific research funds; audit department will audit research funding as the next period the focus of the work period.

The important speeches made by the relevant departments of the state, provincial and municipal authorities and the important speeches of the leaders stressed the seriousness of the use of research funds and the importance of the management of scientific research funds. Strengthening the management of scientific research funds, standardizing the expenditure of scientific research funds and improving the efficiency of the use of scientific research funds are key tasks in the future of colleges and universities.

All colleges and Universities Based on the documents, also have enacted "project management approach", "scientific research fund management approach" and "research funding indirect cost management measures" and other policies to further standardize the use of funds for scientific research and scientific research project management.

Implementation of the funds management of scientific research projects and the reform of relevant policies.

Improving the management system of funds and raising the level of scientific research management.(1) improve the learning and communication system. One is the organization and related management personnel responsible for the issue, to seriously study the spirit of the documents of the state, provincial and municipal scientific research funds management; two is responsible for the research topic and the Secretary of the special training management of scientific research funds; three is the relevant management personnel and subject for people to participate in the relevant national, provincial and municipal exhibitions research funding management training courses, seminars hundreds of passengers; four is to study and exchange of similar institutions.

(2) improve the management system of scientific research funds. The school has developed a revision, "management measures of scientific research funds (Trial)", "research funding indirect funds management approach (Trial)", "research budget adjustment," management measures "research important change Interim Provisions" and other management measures; formulate bulk materials procurement approval process, large-scale equipment procurement approval process and large test fee approval process and other procedures. At the same time, the relevant departments of the school will be national, provincial and municipal relevant management measures compiled for the majority of scientific and technical personnel to consult and learning.

The system is effective and the expenditure is reasonable and standardized in general.

Strengthen the process management of scientific research subjects and standardize the use of scientific research funds. (1) implementation of the project implementation progress, real-time monitoring control. Make full use of the scientific research management system in the management of scientific research projects in the process, you can always see the progress of the project, the realization of network management of scientific research projects, improve the supervision efforts, the implementation of the scientific research topic at present, the school's commitment to basically do the completive.

(2) the implementation of the topic of host responsibility system. Giving the host a clear responsibility and authority is the main responsibility for the relevance, authenticity, validity and rationality of the use of research funding.

(3) the implementation of the subject budget review system. Scientific and technological management department, planning finance department, hospital level units, according to the scientific research tasks, according to the relevant requirements of the higher level, to assist the project leader in the preparation of budget, and do a good job of budget review 


\section{The current situation and problems of the use of scientific research funds in Universities}

At present, through the investigation of several universities, scientific research funds are mainly in the following aspects: first, the policy in the management of project director responsibility system, to clear the responsibility and authority of the host, the host is the first person responsible for the use of project funds, in the use of funds according to the project contract budget execution; two, according to the amount of fund grading approval for different amount of expenditures by the project host, functional departments, school leadership, strict examination and approval; three, scientific research funds auditing, audit department, the Department of science and technology, combined with the financial department of scientific research project for irregular sampling; four, scientific research project regular inspection and supervision system, regular inspection of the focus of research projects, or entrust the two units of self, at the same time, the host periodically urge to hold the project schedule, ensure the project completed on time; five, scientific research project of important matters declaration In case of changes in important items such as the project leader, research contents, budget and expenses, a written application shall be submitted to the relevant department.

Through the implementation of the above measures, strengthen research and fund management, the majority of colleges and universities in the use of research funding overall specification is reasonable, but there are also some problems, mainly reflected in: first, not according to the contract and book the use of budget funds, individual subjects, two do not use overruns; earmarking the different items of research funding confusion, three reimbursement; loan reimbursement cycle is too long, not timely; four, the use of funds lag, inconsistent with the schedule; five, after concluding the funds remaining or excessive surplus; six, there is the phenomenon of pre reimbursement.

\section{Some ideas about the management of scientific research funds in the future}

The use of research funding and management responsibility, all departments need to cooperate effectively, the introduction for the University's development policy, will make the management of scientific research funds more perfect, the use of research funding more standardized, scientific research environment more harmonious, more and more scientific research output and research work will be getting better and better. For the management and use of scientific research funds in Colleges and universities in the future, there are some suggestions as follows:

First, make clear the responsibility. Constantly improve the management system of scientific research funds, and make clear the responsibilities of relevant responsible departments and project leaders in the management of scientific research funds.

Two is the scientific budget. Strictly check the project budget, ensure the scientific and reasonable budget preparation, and ensure the smooth development of the project.

Three is to regulate expenditure. The expenditure of the project shall be strictly carried out according to the budget in the task book or in the contract and the relevant regulations of the higher authorities, and the scope of expenditure for scientific research funds shall be standardized.

The four is regular inspection. Relevant departments of colleges and universities regularly supervise and check the use of scientific research funds, so as to ensure the scientific and rational use of scientific research funds.

Five is to organize training. Actively organize scientific research personnel and scientific research management personnel to participate in related projects and funds use training meetings, timely grasp relevant policies and improve the use of scientific research funds.

Six is the management of scientific research funds in the higher financial departments is too rigid. 
The finance department does not consider the characteristics of agricultural scientific research work, but the "node" management of agricultural scientific research funds in accordance with the engineering management methods, results are often not timely disbursement of funds, it is difficult to carry out agricultural scientific research projects in accordance with the financial budget system, or by the end often surprise money phenomenon. In lateral funding, due to the requirements of the relevant departments, the project funds management and enterprise cooperation is equal to the vertical management of funds, these have affected the enthusiasm of scientific research personnel engaged in scientific research and cooperation.

\section{Acknowledgement}

Project supported by Jilin Provincial Education Department (No. JJKH20170329SK)

\section{Reference}

[1] Liu Ting, Qi Nan. Research on the role orientation of scientific research management personnel at universities and colleges [J]. science and Technology Innovation Herald, 2011,27:214.

[2] The study of management functions of scientific research in universities. [J]. science and technology information, 2010,16:127.

[3] Yan Huichao, Lv Jianqiu. Role orientation of local universities in industry university research cooperation [J]. science and technology management research, 2008,11:119-121. 